\title{
Struktur Komunitas Uca Spp. Di Kawasan Hutan Mangrove, Bedul Utara, Taman Nasional Alas Purwo, Jawa Timur
}

\author{
${ }^{1)}$ Muhamad Rizal ${ }^{2)}$, Dewi Febriyanti ${ }^{3)}$, Husna Sabila ${ }^{3)}$, Wahyu Damarwati ${ }^{4)}$, Hanum Isfaeni ${ }^{5)}$ \\ Prodi Biologi/Pendidikan Biologi, FMIPA Universitas Negeri Jakarta (UNJ) \\ E-mail address: hanisfa@yahoo.com
}

\begin{abstract}
The study aims were to determine the community structure of Uca sp.and its environmental factor at the segara anakan north Bedul Alas purwo national park. Research conducted when the lowest tide began on april $24^{\text {th }}, 2017$. At research station, 30 sampling points was determined by purposive sampling method. Samples ware taken by making $1 x 1$ square, space $5 \mathrm{~m}$ between each square and observed with the space $2 m$ between square and observer and after ten minutes then recorded all the species belonging to each plot. Environment parameters measured to determine the diference of environmental factor to structure community of Uca crabs. Samples of crab preserved with formaldehida $4 \%$ and collected in tha jar. Eight species were found in segara anakan north bedul is Uca rosea, Uca perplexa, Uca capricornis, Uca bellator, Uca tetragonon, Uca crassipes, Uca rapax, Uca lactea.
\end{abstract}

Keyword: crab, Uca, mangrove, community structure

\begin{abstract}
Abstrak
Penelitian ini bertujuan untuk mengetahui struktur komunitas dari Uca sp. di kawasan hutan mangrove serta faktor lingkungan yang mempengaruhinya. Penelitian dilakukan pada saat air surut terendah. Penelitian ini dilakukan pada 24 April 2017. Metode yang dilakukan ialah dengan purposive sampling dan dengan menggunakan belt transek. Penelitian dilakukan dengan membuat plot berukuran $2 \mathrm{~m} \times 2 \mathrm{~m}$ sebanyak 30 plot dan dengan jarak antar plot ialah $5 \mathrm{~m}$. Penelitian dilakukan dengan pengamatan dari jarak $2 \mathrm{~m}$ dan setelah 10 menit kemudian di catat semua spesies yang termasuk ke dalam tiap plot. Dilakukan pengukuran parameter lingkungan untuk mengetahui perbedaan faktor lingkungan terhadap struktur komunitas kepiting Uca. Spesies kepiting yang telah tercatat diambil individunya untuk dijadikan sampel dan dilakukan identifikasi kemudian diawetkan di dalam botol selai dengan menggunakan formalin $4 \%$. Sebanyak 8 jenis kepiting Uca yang ditemukan di hutan mangrove kawasan Bedul, yaitu Uca rosea, Uca perplexa, Uca capricornis, Uca bellator, Uca tetragonon, Uca crassipes, Uca rapax, Uca lactea.
\end{abstract}

Kata kunci: kepiting, Uca, hutan bakau, struktur komunitas

\section{PENDAHULUAN}

A. Latar Belakang

Taman Nasional Alas Purwo yang terletak di terletak di kecamatan Tegaldelimo serta Purwoharjo kabupaten Banyuwangi merupakan kawasan pelestarian dan konservasi alam di Indonesia yang ditetapkan sejak tahun 1993. Taman Nasional Alas Puwo memiliki keanekaragaman biota darat maupun perairan yang sangat berpotensi. Salah satu biota laut yang penting baik bagi ekosistem pesisir laut maupun pemanfaatan untuk pemenuhan gizi masyarakat yaitu biota dari superkelas Crustacea.

Sebagai ekosistem pesisir laut, hutan mangrove memiliki peranan yang penting diantaranya mencegah intrusi air laut ke daratan, sebagai habitat dan tempat mencari makan bagi beberapa organisme, tempat pemijahan dan lain sebagainya. Ekosistem mangrove sangat dipengaruhi oleh beragam factor lingkungan yaitu seperti iklim, curah hujan, kondisi laut serta kondisi substrat (Sandi, 1984). 
Kepiting Uca (Crustacea: Brachyura: Ocypodidae) ialah kepiting mangrove yang memiliki warna dan memiliki perbedaan sistematik luar antar individu berbeda kelamin di dalam satu spesies yang mencolok yaitu dengan adanya capit asimetri pada jantan dewasa sedangkan capit pada betina berukuran sama. Pada jantan, satu capit berukuran sagat besar jika dibandingkan dengan capit lainnya. Capit besar pada kepiting uca jantan berfungsi sebagai alat untukn pertahanan diri, menarik perhatian kepiting betina dan sebagai alat komunikasi, sedangkan capit kecil dapat berguna sebagai alat untuk mengambil makanan dan menggali lubang. Bentuk dan ukuran capit dalam satu kelompok kepiting genus Uca sangat bervariasi (Crane, 1975; Rosenberg, 2001; Naderloo et al., 2010).

Kepiting dari genus Uca jika hidup dalam lingkungan yang mendukung dapat bertahan hidup hingga 3 sampai 4 tahun. Dalam habitatnya, kepiting Uca spp. ini berperan sebagai pemakan detritus (Suprayogi, 2014). Habitat Uca spp. di daerah intertidal, terutama di sekitar hutan mangrove dan pantai berpasir. Kepiting ini ditemukan di pantai terlindung dekat teluk yang besar atau laut terbuka, kadang-kadang hanya terlindung oleh karang atau lumpur laut. Uca spp. merupakan salah satu kepiting kecil, semi-terrestrial yang memiliki peran penting dalam ekologi mangrove tropis (Pratiwi, 2007). Kepiting biola berperan dalam menjaga keseimbangan rantai makanan dan siklus nitrogen dalam ekosistem mangrove. Lubang kepiting meningkatkan aerasi, memudahkan pengeringan tanah, dan menunjang pertukaran unsur hara antara sedimen dan perairan pasang surut.

Struktur komunitas merupakan suatu gambaran secara umum mengenai suatu komunitas dan karakteristiknya yang meliputi komposisi jenis, dominansi jenis, dan indeks keanekaragaman jenis (Setiawan, 2006). Struktur komunitas suatu kelompok makhluk hidup dapat dipelajari berbagai aspek yaitu seperti dominansi jenis, keanekaragaman jenis, dan pola persebaran jenis. Dominansi jenis yaitu suatu jenis makhluk hidup yang memiliki jumlah yang terbanyak, memiliki biomassa yang tinggi yang menempati suatu permukaan yang luas serta memiliki pengaruh yang besar dalam aliran energi dan siklus materi (Smith, 1990). Keanekaragaman jenis ditentukan oleh indeks keanekaragaman jenis dan kesamarataan distribusi individu. Pola persebaran suatu jenis menunjukkan posisi relative individu satu dengan individu lainnya berdasarkan ruang. Terdapat tiga pola persebaran populasi yaitu seragam, acak, dan mengelompok (Odum, 1998).

Struktur komunitas di suatu tempat dipengaruhi oleh faktor lingkungan. Suhu merupakan salah satu faktor yang penting dalam mengatur proses kehidupan dan penyebaran organisme. Suhu mempengaruhi kehidupan dan perkembangbiakan dari tiap biota laut. Biota laut khususnya anggota Crustacea memiliki batas toleransi yang berbeda terhadap suhu. Menurut Laevastu dan Hela (1982), suhu berpengaruh terhadap proses metabolism seperti pertumbuhan, pengambilan makan, aktivitas tubuh seperti kecepatan renang serta berpengaruh terhadap impuls saraf.

Salinitas didefinisikan sebagai jumlah berat garam yang terlarut dalam satu liter air yang biasanya dinyatakan dalam satuan $0 / 00$ (per mil, gram perliter). Sekelompok Crustacea seperti udang laut merupakan jenis yang tidak dapat bertahan hidup pada kondisi perubahan salinitas yang ekstrim (Reddy, 1993). Salinitas dapat berpengaruh terhadap persebarn Crustacea baik vertical maupun horizontal yang secara tidak langsung dapat merubah komposisi organisme dalam ekosistem (Odum dalam Syamsurisal, 2011).

Derajat keasaman atau $\mathrm{pH}$ air menunjukkan kandungan ion hidrogen dalam larutan tersebut dan dinyatakan sebagai konsentrasi ion hidrogen (dalam mol per liter) pada suhu tertentu atau dapat ditulis $\mathrm{pH}=-\log (\mathrm{H})+($ Kordi dan Tancung, 2007). Perubahan $\mathrm{pH}$ perairan dapat merubah keanekaragaman, kelimpahan serta distribusi dari biota laut. Derajat keasaman $(\mathrm{pH})$ mempengaruhi ketersediaan nutrisi dan akan 
membatasi kehidupan suatu organisme yang tidak tahan terhadap asam.

Faktor lingkungan yang berpengaruh berupa suhu, salinitas, kecepatan arus, penetrasi cahaya. Faktor lingkungan berpengaruh pada pola persebaran dan kelimpahan Crustaceae. Oleh karna itu, pada penelitian ini akan di ukur parameter lingkungan di zona intertidal. Untuk mengetahui hubungan factor lingkungan dengan kelimpahan, kekayaan dan komposisi jenis dari kepiting Uca spp.

\section{BAHAN DAN METODE}

\section{A. Alat dan Bahan}

Alat yang digunakan adalah pasak 16 buah, tali raffia satu gulung besar, botol selai 15 buah, Kertas anti air, papan jalan, pulpen, spidol, meteran gulung, kamera digital, gunting, GPS, termometer, $\mathrm{Ph}$ meter, salinometer. Bahan yang digunakan adalah alkohol $70 \% 2$ Liter, formalin 4\% sebanyak 1 liter, plastik specimen (1 pack), kertas label.
Nasional Alas Purwo Banyuwangi, Jawa Timur. Waktu penelitian yaitu pada tanggal 24 April 2017. Pengamatan di lakukan pada pukul 10.00-15.00 WIB. Penelitian ini dilakukan dengan metode deskriptif dan survei dilakukan dengan teknik purposive sampling. Sampling dilakukan dengan menggunakan metode belt transek. Dibuat sebanyak 30 plot berukuran $2 \times 2 \mathrm{~m}^{2}$ dengan jarak antar plot $5 \mathrm{~m}$. Tiap plot dibuat dengan menggunakan 4 pasak dan dihubungkan dengan tali raffia. Semua plot diletakkan mendatar di pinggir aliran air. Tiap anggota kelompok mengamati kepiting Uca pada tiap plot. Pengamatan dilakukan 10 menit setelah pemasangan plot dan diamati dari jarak \pm 2 $\mathrm{m}$. Semua jenis kepiting Uca yang terdapat di dalam plot diamati dan dicatat beserta karakteristiknya. Dilakukan pengukuran faktor-faktor lingkungan yaitu suhu perairan, $\mathrm{pH}$, dan salinitas. Pengambilan sampel kepiting dilakukan dengan menggunakan alat tangkap dan di masukkan ke dalam botol selai kemudian dilakukan identifikasi

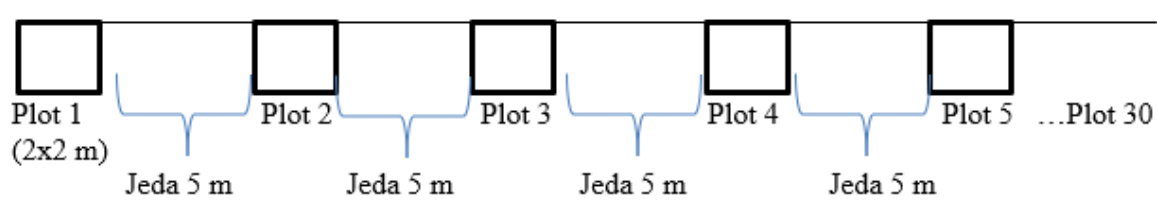

B. Prosedur Penelitian

spesies.

Penelitian ini dilakukan di Kawasan Hutan Mangrove Bedul Utara, Taman

Gambar 1. Metode Belt Transek

\section{Analisis Data}

1. Kelimpahan spesies

Kelimpahan $: B=\frac{\mathrm{T} \times \mathrm{P}}{\mathrm{A} \times \mathrm{S}}$

Keterangan :

$\mathrm{B}=$ kelimpahan individu $/ \mathrm{m}^{2}$

$\mathrm{T}=$ luas satu $\mathrm{m}^{2}\left(10000 \mathrm{~cm}^{2}\right)$

$\mathrm{A}=$ luas transek pengambilan $\left(\mathrm{cm}^{2}\right)$

$\mathrm{P}=$ jumlah individu species ke-i

$\mathrm{S}=$ jumlah transek pengambilan
Rumus yang digunakan untuk menghitung keanekaragaman adalah rumus Indeks Shannon-Wiener (Odum, 1993).

Keanekaragaman Spesies:

$$
\mathrm{H}^{\prime}=-\sum\left(\frac{\mathrm{ni}}{\mathrm{N}}\right) \log \left(\frac{\mathrm{ni}}{\mathrm{N}}\right)
$$

Keterangan :

$\mathrm{H}^{\prime}=$ Keanekaragaman Spesies

$N i=$ Nilai kepentingan untuk tiap spesies

$N=$ Nilai kepentingan total

2. Indeks keanekaragaman spesies 
Klasifikasi Nilai indeks keanekaragaman

Shannon-Wiener seperti tabel berikut:

Tabel 1. Nilai Indeks Keanekaragaman Shanon-Wiener

-Nilai $0.75<\mathrm{D} \leq 1.00$, Dominansi tinggi

\begin{tabular}{|c|l|}
\hline Nilai indeks & \multicolumn{1}{c|}{ Kategori } \\
\hline$>3$ & $\begin{array}{l}\text { Keanekaragaman tinggi, penyebaran jumlah individu tiap spesies } \\
\text { tinggi dan kestabilan komunitas tinggi }\end{array}$ \\
\hline $1-3$ & $\begin{array}{l}\text { Keanekaragaman sedang, penyebaran jumlah individu tiap spesies } \\
\text { sedang dan kestabilan komunitas sedang }\end{array}$ \\
\hline$<1$ & $\begin{array}{l}\text { Keanekaragaman rendah, penyebaran jumlah individu tiap spesies } \\
\text { rendah dan kestabilan komunitas rendah }\end{array}$ \\
\hline
\end{tabular}

3. Indeks dominansi

Dominansi dihitung dengan rumus:

$$
C=\sum\left(\frac{n i^{2}}{N^{2}}\right)
$$

Keterangan :

$\mathrm{ni}=$ Jumlah individu spesies ke-i

$\mathrm{N}=$ Jumlah total individu

Dengan kriteria:

-Nilai $0<\mathrm{D} \leq 0.5$, Dominansi rendah

-Nilai $0.5<\mathrm{D} \leq 0.75$, Dominansi sedang
3. HASIL DAN PEMBAHASAN

A. Jenis Kepiting Biola (Uca spp.)

Berdasarkan hasil penelitian terdapat 8 jenis kepiting biola (Uca spp.)

Pada penelitian ini, di ekosistem mangrove kawasan Bedul Utara terdapat 8 jenis kepiting dengan genus $U c a$, yaitu $U c a$ rosea, Uca perplexa, Uca capricornis, Uca bellator, Uca tetragonon, Uca crassipes, Uca rapax, Uca lactea

Tabel 2. Data Jumlah Kepiting Uca spp. Tiap Plot

\begin{tabular}{|c|c|c|c|c|c|c|c|c|c|c|}
\hline Plot & $\begin{array}{c}\text { Uca } \\
\text { rose } \\
a\end{array}$ & $\begin{array}{c}\text { Uca } \\
\text { perplex } \\
a\end{array}$ & $\begin{array}{c}\text { Uca } \\
\text { capricorni } \\
s\end{array}$ & $\begin{array}{c}\text { Uca } \\
\text { bellato } \\
r\end{array}$ & $\begin{array}{c}\text { Uca } \\
\text { tetragono } \\
n\end{array}$ & $\begin{array}{c}\text { Uca } \\
\text { crassipe } \\
s\end{array}$ & $\begin{array}{c}\text { Uca } \\
\text { rapa } \\
x \\
\end{array}$ & $\begin{array}{c}\text { Uca } \\
\text { lacte } \\
a\end{array}$ & $\underset{\mathbf{h}}{\text { Jumla }}$ & $\begin{array}{l}\text { Keanekaragama } \\
\text { n }\end{array}$ \\
\hline 1. & 5 & 2 & - & - & 1 & - & - & - & 8 & 0.90 \\
\hline 2. & 2 & 5 & - & 1 & - & 1 & - & - & 9 & 1.15 \\
\hline 3. & 8 & 5 & 1 & 2 & - & - & - & - & 16 & 1.13 \\
\hline 4. & 48 & 7 & 2 & 2 & - & - & - & - & 59 & 0.64 \\
\hline 5. & 11 & 18 & 2 & - & - & - & - & 19 & 50 & 1.19 \\
\hline 6. & - & 1 & 1 & 1 & - & - & 1 & 15 & 19 & 1.59 \\
\hline 7. & - & 43 & 2 & 2 & - & 8 & 1 & 1 & 57 & 0.78 \\
\hline 8. & 11 & 28 & - & - & - & - & - & - & 39 & 0.60 \\
\hline 9. & - & 6 & 1 & - & 1 & 19 & - & 2 & 29 & 1.02 \\
\hline 10. & 13 & 18 & - & - & - & 1 & - & - & 32 & 0.36 \\
\hline 11. & 11 & 1 & - & 1 & 1 & - & - & - & 14 & 3.99 \\
\hline 12. & 18 & 28 & - & 11 & - & 1 & - & 4 & 62 & 1.04 \\
\hline 13. & 4 & 15 & 1 & 4 & 3 & - & - & - & 27 & 1.35 \\
\hline 14. & 12 & 8 & - & 1 & - & 2 & - & 1 & 24 & 1.60 \\
\hline 15. & 17 & 12 & 1 & 5 & - & 13 & - & - & 48 & 1.24 \\
\hline 16. & 12 & 7 & 3 & 4 & 4 & - & 1 & - & 31 & 1.37 \\
\hline 17. & 28 & 24 & 3 & 3 & - & 7 & - & - & 65 & 1.38 \\
\hline 18. & 4 & 2 & 9 & 5 & - & 4 & - & 1 & 25 & 1.58 \\
\hline 19. & 21 & 10 & 5 & 2 & - & 9 & - & - & 47 & 1.45 \\
\hline 20. & - & 15 & 3 & - & - & - & - & 4 & 22 & 1.03 \\
\hline 21. & 31 & 17 & 2 & - & - & - & - & 10 & 60 & 1.11 \\
\hline
\end{tabular}




\begin{tabular}{ccccccccccc}
\hline 22. & 25 & 12 & - & - & - & - & - & - & $\mathbf{3 7}$ & $\mathbf{0 . 6 3}$ \\
\hline 23. & 5 & 14 & - & 7 & - & 12 & - & 18 & $\mathbf{5 6}$ & $\mathbf{1 . 4 9}$ \\
\hline 24. & 50 & 18 & 4 & - & 1 & - & - & - & $\mathbf{7 3}$ & $\mathbf{0 . 8 2}$ \\
\hline 25. & - & 5 & - & 5 & - & 14 & - & 1 & $\mathbf{2 5}$ & $\mathbf{1 . 0 9}$ \\
\hline 26. & 71 & 22 & 5 & 8 & - & - & - & - & $\mathbf{1 0 6}$ & $\mathbf{0 . 9 3}$ \\
\hline 27. & 42 & 12 & - & - & - & - & - & - & $\mathbf{5 4}$ & $\mathbf{0 . 5 3}$ \\
\hline 28. & - & - & - & - & - & - & - & - & $\mathbf{0}$ & - \\
\hline 29. & 3 & 1 & 3 & 19 & - & - & - & 1 & $\mathbf{2 7}$ & $\mathbf{1 . 0 9}$ \\
\hline 30. & 13 & 11 & 7 & - & - & - & - & - & $\mathbf{3 1}$ & $\mathbf{0 . 9 7}$ \\
\hline $\begin{array}{c}\text { Jumla } \\
\text { h }\end{array}$ & $\mathbf{4 6 5}$ & $\mathbf{3 6 7}$ & $\mathbf{5 5}$ & $\mathbf{8 3}$ & $\mathbf{1 1}$ & $\mathbf{9 1}$ & $\mathbf{3}$ & $\mathbf{7 9}$ & $\mathbf{1 1 5 4}$ &
\end{tabular}

\section{B. Jenis-Jenis $\boldsymbol{U} c a$ sp. \\ 1. Uca rosea}

Variasi warna yang dominan ditemukan adalah warna dark orange. Pada Uca.rosea, bagian manus terlihat lebih dominan apabila dibandingkan dengan bagian pollex dan dactyl. Bentuk karapas pada jantan dan betina tidak berbeda. Bagian abdomen jantan berbeda dengan betina dimana pada jantan, struktur abdomen lebih memanjang sedangkan pada betina lebih tumpul dan lebar. Ukuran lebar karapas jantan dapat mencapai $27.5 \mathrm{~mm}$ dan lebar karapas betina dewasa mencapai $17.5 \mathrm{~mm}$. Daerah hidup Uca.rosea yaitu pada substrat lumpur dekat sungai dan selalu dekat vegetasi.

2. Uca perplexa

Karapas pada Uca perplexa berwarna hitam gelap dengan bercak putih melintang pada karapasnya. Merus, carpus, dan manus berwarna kuning sementara dactyl dan polex berwarna putih. Ukuran tubuh dewasa berkisar $30-75 \mathrm{~mm}$. banyak ditemukan pada kawasan terbuka dan berpasir. Persebarannya yaitu pada daerah Indonesia, Hongkong, Jepang, dan China(Crane, 1975).

3. Uca capricornis

Karapas berwarna hitam, terdapat spot berwarna biru kehijauan pada karapas dan capitnya. Biasanya warna spot ini terdapat pada kepiting betina dewasa tapi tidak ada di kepiting jantan dewasa. Uca capricornis ditemukan pada titik penelitian yang berbatasan dengan air sungai pada hutan mangrove, serta substrat yang memiliki kadar air yang tinggi. Menurut Prianto (2007) menyatakan bahwa Uca capricornis juga bersifat semiterestrial yang aktif pada saat air surut dan masuk kedalam lubangnya saat air pasang

\section{Uca bellator}

Memiliki bagian depan atau frontal karapas yang melebar, lebar karapas mencapai 30mm. Sudut luar orbit melengkung tajam, bagian dasar orbit terdiri dari deretan pendek granula. Capit besar tertutup oleh granula kecil dan halus, permukaan luar daktilus terdapat alur yang panjang, pada bagian polleks berbentuk segitiga.

Pada Uca belator jantan memilki warna karapas coklat dengan tanda biru atau putih atau kedua warna tersebut memiliki merus berwarna mera, orange kecoklatan atau kuning kusam bagian bawah marus orange hingga orange kecoklatan dan bagian atas marus putih dengan tangkai mata terkadang kuning kehijauan maxiliped,suborbital dan ambulatories seluruhnya gelap dengan spot keputihan

\section{Uca tetragonon}

Kepiting ini memiliki warna tubuh biru mencolok dengan sedikit bintik putih . Uca tetragonon merupakan kepiting mangrove dan memiliki persebaran yang luas. Karapas terdapat alur-alur bagian depan secara melebar. Karapas tidak terlalu mengkung. Jantan memiliki ukuran panjang tubuh sekitar $21.5 \mathrm{~mm}$ dan lebar sekitar $33.5 \mathrm{~mm}$. Betina memiliki ukuran panjang sekitar 17.5 $\mathrm{mm}$ dan lebar mencapai $32 \mathrm{~mm}$.

Yulianto (2006) menyatakan bahwa kepadatan jenis Uca tetragonon 
Jurnal Parameter Volume 29 No. 1

DOI : doi.org/10.21009/parameter.291.04

P-ISSN : 0216-26IX

dipengaruhioleh tingginya frekuensi habitat terendam air. Menurut Suzuki dan Hatori (1998) dalam suatu populasi jenis Uca tetragonon betina lebih sering ditemukan daripada yang jantan, sehingga pemanfaatan capit yang besar untuk berkompetisi tidak bisa dilakukan yang menyebabkan individu semakin berkurang.

\section{Uca crassipes}

Uca crassipes, banyak ditemukan di zona intertidal hilir di daerah yang relatif terbuka, menurut Gerarld (2007) . Uca crassipes memiliki lebar karapas sekitar 2,1 $\mathrm{cm}$, warna karapaks merah-hitam dan memiliki panjang tubuh $2 \mathrm{~cm}$. karapas berbentuk trapesium berwarna merah, orbit tidak tampak merus, carpus dan manus berwarna merah, halus, dactyl dan pollex berwarna merah dengan ujung berwarna putih., memiliki 4 pasang kaki jalan dan sepasang capit yang berwarna orange, ukuran capit sebelah kiri lebih besar dan capitnya memiliki ujung yang sedikit meruncing dan di bagian dalamnya terdapat gerigi-gerigi. Eye stalknya sedikit panjang dan memilki mata berwarna merah.

7. Uca rapax
U.rapax merupakan kepiting yang dimorfik karena karena pejantan dicirikan dengan salah satu capitnya besar, sedangkan betinanya memiliki ukuran capit yang sama. Pejantan memiliki lebar karapas 13-15 mm sedangkan betina memiliki lebar 11-12 mm. jantan dan betina memiliki warna yang sama dari keabu-abuan hingga berwarna putih, serta hijau kebiruan pada capit dan batang matanya. Warna tergantung pada faktor lingkungan, ditemukan pula yang berwarna jingga dan kuning di capitnya.

\section{Uca lactea}

Uca lactea memiliki warna karapas berwarna putih polos, pada sepesies lain memiliki warna seperti keramik. Spesies ini memiliki lebar karapas $\pm 15 \mathrm{~mm}$. Kakinya berwarna putih polos, selain itu ada juga disertai pola bintik-bintik berwarna abu-abu dan capit besarnya berwarna putih, dactyl lebih panjang dari pollex dan pada ujung dactyl berbentuk seperti kait. Abdomen pada Uca lactea betina lebih lebar dibandingkan dengan abdomen pada $U c a$ lactea jantan. Uca lactea ditemukan di daerah yang berpasir di hutan mangrove yang terbuka.

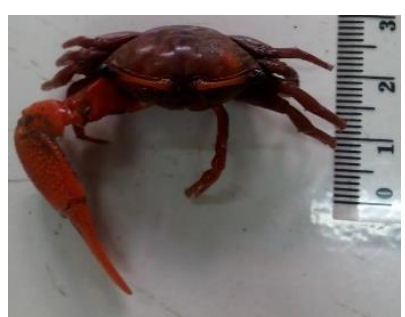

A

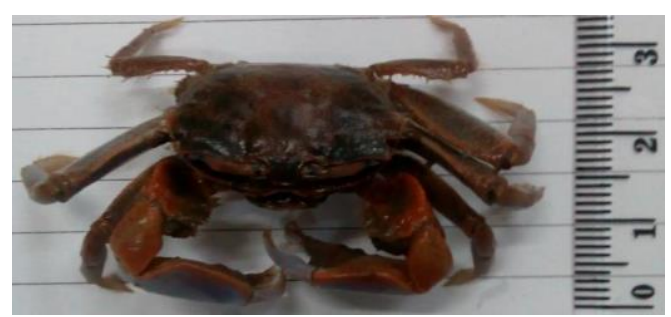

B

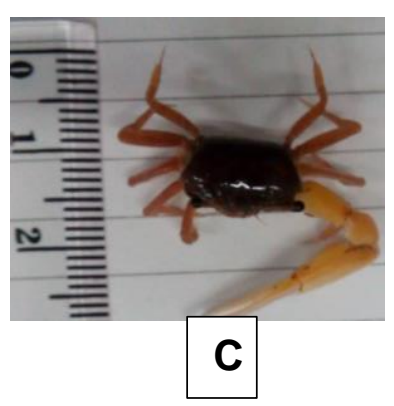

Gambar 2. (a) Uca rosea, (b) Uca crassipes, (c) Uca perplexa

\section{Kelimpahan dan Komposisi Jenis kepiting Uca spp. di Ekosistem Mangrove Bedul Utara.}

Berdasarkan hasil pengamatan dan analisis, data kelimpahan individu tiap spesies dan kelimpahan jenisnya diperlihatkan dalam Tabel 3 berikut ini:
Tabel 3. Kelimpahan individu tiap spesies per meter persegi dan komposisi jenis

\begin{tabular}{lcccc} 
Jenis & $\begin{array}{c}\text { Jumla } \\
\mathbf{h} \\
\text { Individ } \\
\mathbf{u}\end{array}$ & $\begin{array}{c}\text { Jumla } \\
\text { h Plot }\end{array}$ & $\begin{array}{c}\text { Kelimpah } \\
\text { an } \\
\text { individu/ } \\
\mathbf{m}^{\mathbf{2}}\end{array}$ & $\begin{array}{c}\text { Kompos } \\
\text { isi Jenis }\end{array}$ \\
\hline $\begin{array}{l}\text { Uca } \\
\text { rosea }\end{array}$ & 465 & 24 & 4.84 & 40.29 \\
\hline
\end{tabular}




\begin{tabular}{lcccc}
\hline $\begin{array}{l}\text { Uca } \\
\text { perplexa }\end{array}$ & 367 & 29 & 3.16 & 31.80 \\
\hline $\begin{array}{l}\text { Uca } \\
\text { capricor } \\
\text { nis }\end{array}$ & 55 & 18 & 0.76 & 4.77 \\
\hline $\begin{array}{l}\text { Uca } \\
\text { bellator }\end{array}$ & 83 & 18 & 1.15 & 7.19 \\
\hline $\begin{array}{l}\text { Uca } \\
\text { tetragon } \\
\text { on }\end{array}$ & 11 & 6 & 0.46 & 0.95 \\
\hline $\begin{array}{l}\text { Uca } \\
\text { crassipe } \\
\text { s }\end{array}$ & 91 & 12 & 1.89 & 7.89 \\
\hline $\begin{array}{l}\text { Uca } \\
\text { rapax }\end{array}$ & 3 & 3 & 0.25 & 0.26 \\
\hline $\begin{array}{l}\text { Uca } \\
\text { lactea }\end{array}$ & 79 & 12 & 1.65 & 6.85 \\
\hline Jumlah & $\mathbf{1 1 5 4}$ & & $\mathbf{1 4 . 1 6}$ & $\mathbf{1 0 0}$ \\
\hline
\end{tabular}

Dari tabel diatas didapatkan hasil bahwa komposisi jenis Uca rosea dengan persentase sebesar 40.29\%, jenis Uca perplexa dengan persentase $31.80 \%$, jenis Uca capricornis dengan persentase $4.77 \%$, jenis Uca bellator dengan persentase $7.19 \%$, jenis Uca tetragonon dengan persentase $0.95 \%$, jenis Uca crassipes dengan persentase $7.89 \%$, jenis Uca rapax dengan persentase $0.26 \%$, dan jenis Uca lactea dengan persentase $6.85 \%$

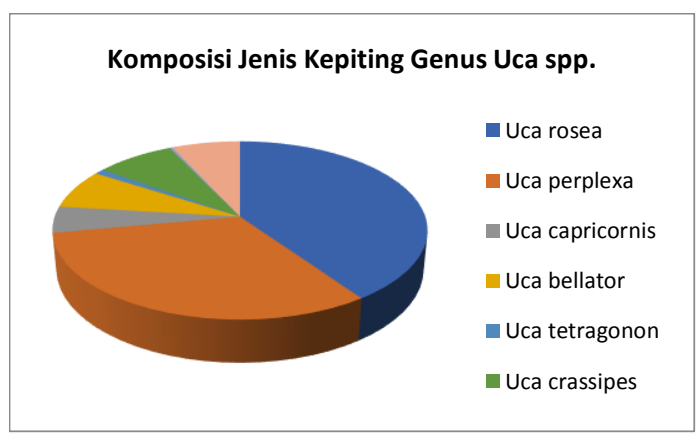

Gambar 3. Grafik Komposisi Jenis Kepiting Dari Genus Uca spp.

Berdasarkan tabel dan gambar grafik, dapat diketahui bahwa jenis kepiting yang memiliki komposisi tertinggi yaitu jenis Uca rosea dengan persentase jenis $40.29 \%$. Melihat dari hasil tersebut dapat dikatakan bahwa jenis kepiting Uca rosea paling banyak ditemukan di ekosistem mangrove, kawasan Bedul Utara. Jumlahnya yang tinggi pada ekosistem mangrove kawasan Bedul Utara diduga jenis ini memiliki persebaran yang luas. Sedangkan jumlah kepiting dengan komposisi terendah yaitu jenis $U c a$ rapax dengan persentase $0.26 \%$. Jumlahnya yang sedikit ini menunjukkan bahwa persebarannya yang sempit di ekosistem mangrove Bedul Utara.

\section{Indeks Keanekaragaman dan Dominansi}

Keanekaragamanmerupakan jumlah dan kelimpahan relatif dari spesies dalam sebuah komunitas biologis (Campbell dan Reece, 2008). Hasil analisis Indeks Keanekaragaman, Keseragaman, dan Dominansi dapat dilihat pada tabel 4.

Tabel 4. Indeks Keanekaragaman dari masing-masing spesies

\begin{tabular}{lccc}
\hline \multicolumn{1}{c}{ Jenis } & $\begin{array}{c}\text { Jumlah } \\
\text { Individ } \\
\mathbf{u}\end{array}$ & $\begin{array}{c}\text { Indeks } \\
\text { Keanekaragama } \\
\mathbf{n}\end{array}$ & $\begin{array}{c}\text { Dominan } \\
\mathbf{s i}\end{array}$ \\
\hline Uca rosea & 465 & 0.36 & 0.162 \\
\hline $\begin{array}{l}\text { Uca } \\
\text { perplexa }\end{array}$ & 367 & 0.36 & 0.101 \\
\hline $\begin{array}{l}\text { Uca } \\
\text { capricorni } \\
\text { s }\end{array}$ & 55 & 0.14 & 0.002 \\
\hline $\begin{array}{l}\text { Uca } \\
\text { bellator }\end{array}$ & 83 & 0.19 & 0.005 \\
\hline $\begin{array}{l}\text { Uca } \\
\text { tetragono } \\
n\end{array}$ & 11 & 0.04 & 0.000 \\
\hline $\begin{array}{l}\text { Uca } \\
\text { crassipes }\end{array}$ & 91 & 0.20 & 0.006 \\
\hline $\begin{array}{l}\text { Uca rapax } \\
\text { Uca }\end{array}$ & 3 & 0.015 & 0.000 \\
\hline lactea & 79 & 0.18 & 0.004 \\
\hline Jumlah & $\mathbf{1 1 5 4}$ & $\mathbf{1 . 4 8 5}$ & $\mathbf{0 . 2 8 2}$ \\
\hline
\end{tabular}

Berdasarkan hasil analisis tersebut didapati hasil Indeks Keanekaragaman sebesar 1.485 dan dikategorikan kedalam kategori sedang. Hal ini menunjukkan bahwa kondisi lingkungan dalam kondisi yang cukup baik namun kemungkinan terjadi sedikit gangguan pada lingkungan sehingga tingkat keanekaragaman tidak tergolong tinggi. Keanekaragaman mencakup dua hal penting yaitu banyaknya jenis yang ada dalam suatu komunitas dan kelimpahan dari masing masing jenis tersebut, sehingga makin kecil jumlah jenis dan variasi jumlah individu tiap jenis atau ada beberapa individu yang jumlahnya jauh lebih besar, maka 
Jurnal Parameter Volume 29 No. 1

DOI : doi.org/10.21009/parameter.291.04

P-ISSN : 0216-26IX

keanekaragaman suatu ekosistem akan mengecil (Odum, 1971)

Berikut diberikan hasil pengukuran indeks keanekaragaman dan dominansi beserta kategorinya.

Tabel 5. Indeks Keanekaragaman dan Dominansi

\begin{tabular}{ccc}
\hline \multicolumn{1}{c}{ Indeks } & Nilai & Kategori \\
\hline Keanekaragaman $(\mathrm{H})$ & 1.485 & Sedang \\
\hline Dominansi $(\mathrm{C})$ & 0.282 & Rendah \\
\hline
\end{tabular}

Indeks dominansi didapatkan hasil dengan kategori dominansi yang rendah. Hal ini mencirikan bahwa terdapatnya dominansi kepiting walau dalam kategori rendah. Berdasarkan analisis menunjukkan bahwa jenis yang memiliki kelimpahan tertinggi ialah dari spesies Uca rosea yang menunjukkan dominansinya pada kawasan mangrove di Bedul Utara.

\section{PARAMETER LINGKUNGAN}

Terdapat 30 plot dalam pengambilan data Uca sp, setiap 5 plot diambil data parameter lingkungan meliputi Suhu, Salinitas, dan PH.

Tabel 6. Parameter Lingkungan

\begin{tabular}{|c|c|c|c|}
\hline $\begin{array}{l}\text { Data } \\
\text { Fisik }\end{array}$ & Suhu & Salinitas & $\begin{array}{c}\text { Derajat } \\
\text { Keasaman } \\
(\mathrm{pH})\end{array}$ \\
\hline 1 & $32.8^{\circ} \mathrm{C}$ & $15 \%$ & 8.1 \\
\hline 2 & $33.8^{\circ} \mathrm{C}$ & $19.7 \%$ & 7.8 \\
\hline 3 & $34.2^{\circ} \mathrm{C}$ & $13.7 \%$ & 7.95 \\
\hline 4 & $33.1^{\circ} \mathrm{C}$ & $18.3 \%$ & 8 \\
\hline 5 & $36.5^{\circ} \mathrm{C}$ & $18 \%$ & 8.2 \\
\hline 6 & $\begin{array}{l}34.1 \\
{ }^{\circ} \mathrm{C} \\
\end{array}$ & $\begin{array}{l}18.6 \\
\% о\end{array}$ & 7.2 \\
\hline
\end{tabular}

didapatkan bahwa suhu berkisar antara 32.8$36.5^{\circ} \mathrm{C}$. Umumnya organisme aquatic memerlukan suhu optimum berkisar antara $20-30^{\circ} \mathrm{C}$.sedangkan suhu optimum untuk beberapa jenis kepiting adalah $26-30{ }^{\circ} \mathrm{C}$ (Romimohtarto \& Juwana, 2001).

Pada stasiun penelitian, suhu yang diambil berada pada kisaran $32,8-36.5^{\circ} \mathrm{C}$. stasiun tempat penelitian juga merupakan areal terbuka yang terkena paparan sinar matahari. Jumlah organisme terbanyak berada pada plot ke 24 dan plot ke 26 . Hal ini berkaitan dengan suhu dimana pada plot tersebut, tercatat suhu masing-masing yaitu 36.5 dan $34.1^{\circ} \mathrm{C}$. suhu memiliki keterkaitan dengan reaksi biokimia pada tubuh uca, dimana akan terjadi peningkatan reaksi menjadi dua kali lipat tiap pertambahan suhu $10^{\circ}$ C. setiap kenaikan tersebut terjadi peningkatan penggunaan oksigen. Akan tetapi pada rentang suhu 30-32 terdapat penurunan konsumsi oksigen akibat pengaruh tekanan suhu.

$\mathrm{Ph}$ juga mempengaruhi banyaknya uca $\mathrm{pH}$ yang $<5$ dan $\mathrm{pH}>9$ akan menciptakan kondisi yang tidak menguntungkan bagi kehidupan makrozoobentos termasuk Crustaceae. Kisaran pH pada stasiun penelitian yaitu 7,2- 8,2. Karena berada pada kisaran $5<\mathrm{Ph}<9$ sehingga dapat dikatakan bahwa $\mathrm{pH}$ pada stasiun penelitian sesuai dengan ph untuk uca.

Pada penelitian salinitas pada daerah penelitian berkisar antara 13,7 hingga 18 per mili salinitas tersebut amat baik sebagai habitat uca menurut (kordi 1997) kepiting bakau hidup dengan baik pada kisaran salinitas 10- 35, dan terdapat beberapa peneliti mengatakan kepiting bakau dapat hidup baik pada kisaran salinitas 15-35.

\section{KESIMPULAN}

a. Hasil dari pengambilan sampel di daerah kawasan hutan mangrove bedul utara, Taman Nasional Alas Purwo didapatkan 8 spesies dengan jenis Uca rosea,Uca perplexa,Uca capriconis, Uca tentragon,Uca crassipes, Uca rapax dan Uca lactea

b. Dari data kelimpahan didapatkan hasil bahwa komposisi jenis dengan presentase terbesar adalah Uca rosea dengan persentase sebesar $40.29 \%$, serta Uca rapax dengan persentase terkecil sebesar $0.26 \%$.

c. Pada Indeks Keanekaragaman diperoleh nilai sebesar 1.485 dan dikategorikan kedalam kategori sedang. Hal ini menunjukkan bahwa kondisi lingkungan dalam kondisi yang cukup baik namun kemungkinan terjadi sedikit gangguan 
pada lingkungan sehingga tingkat keanekaragaman tidak tergolong tinggi.

d. Pada Indeks dominansi dikategorikan dominansi yang rendah. Berdasarkan analisis menunjukkan bahwa jenis yang memiliki kelimpahan tertinggi ialah dari spesies Uca rosea yang menunjukkan dominansinya pada kawasan mangrove di Bedul Utara.

e. Parameter lingkungan seperti suhu, salinitas dan derajat keasaman $(\mathrm{pH})$ mempengaruhi kelimpahan, keanekaragaman, dan dominansi pada Uca.

\section{DAFTAR PUSTAKA}

Abele, I.G. 1982. The Biology of Crustacea: volume 1. Academis Press. New York.

Crane, J. 1975. Fiddler Crabs of the World, Ocypodidae: Genus Uca. Princeton University Press, New Jersey: xxiii + $736 \mathrm{pp}$.

Hela I dan Leavastu. 1982. Fisheries Oceanography new Ocean environmental Service. England: Fhising new book ltd.

Kordi M.GH dan Tancung AB. 2007. Pengelolaan kualitas air. Rineka Cipta. Jakarta

McLusky, D. S. 2004. The estuarine ecosystem. 3rd ed. New York: Chapman \& Hall. Clearly describes the structure and function of estuarine ecosystems. Syamsurisal.2011. Studi Beberapa Indeks Komunitas Malrozoobentos di Hutan Mangrove, Universitas Hassanudin, Makasar.

Naderloo, R., M. Turkay \& H. Chen. 2010. Taxonomic revision of the widefront fiddler crabs of the Uca lactea group (Crustacea: Decapoda: Brachyura: Ocypodidae) in the Indo-West Pacific. Zootaxa 25: 1-38.

Nontji, A. 1993. Laut Nusantara. Djambatan, Jakarta.

Noor Dienti, Dea. 2012. Struktur Komunitas Gastropoda di Keramba Ikan Teluk Lada Perairan Selat Sunda. Program Sarjana Sains, Universitas Negeri Jakarta, Jakarta. Skripsi Program
Sarjana. Munira. 2011. Beberapa Aspek Ekologi Bivalvia Di Daerah Pasang Surut Waling Besar Kepulauan Banda, Maluku. Bimafika 3: 259-265

Odum, P. 1998. Fundamentals of Ecology Third Edition. Yogyakarta: Gadjah Mada University Press.

Pratiwi, R. 2007. Jenis dan Sebaran Uca spp. (Crustacea: Decapoda: Ocypodidae) di Daerah Mangrove Delta Mahakam Kalimantan Timur. Jurnal Perikanan, V IX (2): 322-328

Reddy M.DM. 1993. Influence of The Variouse Oceanographic on The Abundance of Fhis Catch, Proseeding of International Workshop. India.

Rosenberg, M.S. 2001. The systematics and taxonomy of fiddler crabs: A phylogeny of the genus Uca. Journal of Crustacean Biology 21(3): 839-869.

Rumimohtarto, K dan Juwana, S. 1999. Biologi Laut, Ilmu Pengetahuan Tentang Biota Laut. Jakarta: Penerbit Djambatan.

Sandi, I. M. 1984. Mangrove dan Tumbuhannya. Prosiding Seminar II EkosistemMangrove. Jakarta.p. 133 143

Setiawan, D.E. 2006. Struktur Komunitas Alga Laut Makrobentik Di Pantai Gelung Kecamatan Panarukan Kabupaten Situbondo Jawa Timur. Jember: FMIPA Universitas Jember.

Smith, R.L. 1990. Ecology and Field Biology Second Edition. New York: Harper Collins Publishers.

Suprayogi, D. 2014. Keanekaragaman Kepiting Biola (Uca spp) di Desa Tungkal I Tanjung Jabung Barat. Biospesies. 7 (1) : 22-28

Suzuki, H dan H. Hatori. 1998. The Report of JICA Short-term Expert of The Development of Sustainable Mangrove Management Project : Marine Crustacean, Crabs and Bird. p : 169 197.

Yulianto, A. 2006. Keanekaragaman Kepiting di Hutan Mangrove Desa Tungkal, Tanjung Jabung Barat, Jambi. Fakultas Perikanan. Bogor. 